\title{
ANTESEDEN DAN KONSEKUENSI KEPUASAN TERHADAP PENGGUNAAN E-LEARNING PADA MAHASISWA
}

\author{
Margaretha Pink Berlianto \\ Fakultas Ekonomi, Universitas Pelita Harapan \\ margaretha.berlianto@uph.edu
}

\begin{abstract}
This research aims to analyze the effects of self-efficacy, subjective norms, system accessibility, attitudes, and satisfaction on intention to use e-learning among university students. Accordingly, I propose eight hypotheses and test these these hypotheses using the PLS analysis. The results show the following. Firstly, selfefficacy does not affect attitude and intention to use e-learning. Secondly, subjective norms affect attitude and intention to use e-learning. Thirdly, system accessibility has no effect on attitude and intention to use e-learning. Fourthly, attitude affects esatisfaction and lastly e-satisfaction affects intention to use e-learning. This study could provide valuable inputs to universities in implementing e-learning system by suggesting that e-learning system fits the norms and values of society and students exhibit positive attitude towards e-learning. Further, system accessibility is no longer a factor that may affect attitudes and intention to use e-learning because currently there are so many places that offer internet access that students can access e-learning system everywhere without having to rely university-provided system.
\end{abstract}

Keywords: e-satisfaction, subjective norm, self-efficacy, system access, attitude.

\begin{abstract}
ABSTRAK
Tujuan dari penelitian ini adalah menganalis pengaruh self-efficacy, norma subjektif, aksesibilitas sistem, sikap, kepuasan dan niat untuk menggunakan $e$-learning pada sebuah universitas. Pada penelitian ini terdapat delapan hipotesis yang diuji. Pengujiaan masing-masing variabel diukur dengan 5 skala Likert. Pengujian uji kecocokan model dan hipotesis dilakukan dengan analisis PLS. Hasil dari penelitian ini adalah self-efficacy tidak berpengaruh terhadap sikap dan niat untuk menggunakan, subjek normatif berpengaruh terhadap sikap dan niat untuk menggunakan, aksesibilitas sistem tidak berpengaruh terhadap sikap dan niat untuk menggunakan, sikap berpengaruh terhadap kepuasan dan kepuasan berpengaruh terhadap niat untuk menggunakan. Kontribusi penelitian ini adalah memberikan masukan kepada universitas yang mengimplementasikan sistem pembelajaran $e$-learning bahwa sistem e-learning sesuai dengan norma dan nilai masyarakat yang berlaku dan mahasiswa memiliki sikap yang positif terhadap e-learning. Aksesibilitas sistem bukan lagi menjadi kendala yang dapat mempengaruhi sikap dan niat untuk menggunakan mahasiswa dikarenakan pada saat ini sudah banyak tempat yang menyediakan akses internet sehingga mahasiswa dapat mengakses sistem e-learning dimana saja tanpa harus mengandalkan sistem dari universitas.
\end{abstract}

Kata Kunci: kepuasan, norma subjektif, efikasi diri, akses terhadap sistem, sikap. 


\section{PENDAHULUAN}

Sektor pendidikan mengalami dampak dari perkembangan teknologi dan internet. Dampak internet dan teknologi pada dunia pendidikan adalah meningkatnya tren perguruan tinggi mengunakan sistem e-learning yang menyediakan akses dan bahan pembelajaran secara online (Park 2009). Penggunaaan ICT dan e-learning menawarkan kesempatan untuk meningkatkan standar pendidikan di sekolah yang lebih tinggi. E-learning atau pembelajaran secara elektronik mengacu pada pembelajaran yang menggunakan media elektronik. Menurut Ozkan dan Koseler (2009), e-learning mengacu pada penggunaan alat elektronik dalam pembelajaran, termasuk penyampaian materi melalui media elektronik seperti internet, audio atau video, penyiaran melalui satelit, televisi interaktif, radio, CD-ROM dan lainnya. Sedangkan Park (2009) menyatakan bahwa e-learning adalah pembelajaran murni, berbasis web, pembelajaran asynchronous melalui situs intenet yang dioperasikan oleh universitas. E-learning pada penelitian ini difokuskan pada penggunaan Learning Management System-Moodle, yaitu penggunaan moodle pada proses pembelajaran mahasiswa.

Peningkatan tren kenaikan penggunaan e-learning ini juga didukung oleh laporan yang diterbitkan oleh Reseach and Market yang menyatakan bahwa peramalan analisis pasar dan tren industri e-learning secara global pada tahun 2025 akan tumbuh pada CAGR (Compound Annual Growth Rate) 7,2 persen selama satu dekade kedepan dan akan mencapai \$325 miliar pada tahun 2025 (GlobeNewswire 2017). Peningkatan pertumbuhan ini disebabkan karena meningkatnya pembelajaran melalui game, pelaksanaan keamanan teknologi informatika dan solusi berbasis cloud, pertumbuhan pesat dalam konten online dan digitalisasi, inovasi dalam teknologi yang ada membuat e-learning bertumbuh dan sistem manajemen pembelajaran (LMS) yang beralih ke sistem berbasis cloud (GlobeNewswire 2017). Selain itu, berdasarkan data penjualan e-learning di Asia Pasifik pada tahun 2011 sebesar US\$5,2 milliar dan meningkat menjadi US\$10 milliar pada tahun 2015 (Bora 2017). Nilai investasi untuk pengembangan teknologi edukasi di Asia Tenggara hingga akhir tahun 2015 telah mencapai US\$ 170 juta (Kompas 2016)

Pertumbuhan e-learning yang cepat ini tentu saja dikarenakan beberapa keuntungan yang diberikan oleh e-learning seperti e-learning menyediakan solusi untuk pembelajaran yang lebih mudah, menerapakan teknologi tanpa kertas, memelihara standar dan kualitas pendidikan yang tinggi (Naile 2017). Selain itu, menurut Villiers (2017), e-learning sangat baik bagi lingkungan karena mengurangi carbon footprint 85 persen, hemat energi sampai dengan 90 persen dari metode yang lainnya, memungkinkan bagi keterlibatan pelajar yang lebih baik, pelajar dapat belajar lebih cepat dalam periode yang lebih pendek, mendorong retensi pengetahuan, dan lainnya. 
Walaupun e-learning memiliki berbagai keuntungan dan memiliki tren kenaikan dalam penggunaannya, banyak perguruan tinggi yang menyediakan $e$ learning menghadapi kesulitan besar dalam mencapai keberhasilan strategis, termasuk penyampaian, efektivitas dan penerimaan materi pembelajaran (Saadé 2003). Peslak et al., (2007) menemukan bahwa 30 persen dari penerapan teknologi gagal. Alasan kegagalan tersebut diakibatkan oleh karakteristik pelajar, karakteristik sistem $e$ learning tersebut dan dukungan organisasi terhadap penggunaan e-learning (Sawang et al., 2013). Alasan keberhasilan penerapan e-learning adalah kepuasan pelajar dalam menggunakan e-learning (Sachs dan Hale 2003). Pada penelitian yang dilakukan oleh Mayya (2007) menemukan bahwa motivasi untuk menggunakan teknologi informasi dan komunikasi dalam proses pembelajaran harus didukung tersedianya akses terhadap sistem, sehingga faktor aksesibilitas sistem menjadi salah satu faktor yang akan diuji pada penelitian ini.

Penelitian sebelumnya mengenai self-efficacy, subjective norm, aksesibilitas sistem, sikap, kepuasan dan niat pada penelitian terdahulu menemukan hasil yang berbeda. Pada penelitian mengenai norma subjektif dilakukan oleh Kim et al., (2013) menemukan bahwa norma subjektif berpengaruh terhadap sikap tetapi tidak berpengaruh terhadap niat perilaku. Akan tetapi, Voon et al., (2011) menemukan bahwa sikap berpengaruh terhadap behavioral intention. Menurut Al-swidi et al., (2014), sikap berpengaruh positif terhadap behavioral intention akan tetapi menurut Calisir et al., (2009) sikap tidak berpengaruh terhadap behavioral intention. Pada penelitian yang dilakukan oleh Ayo et al., (2016) menemukan bahwa self-efficacy tidak berpengaruh terhadap sikap, akan tetapi hal sebaliknya ditemukan oleh Adesina dan Ayo (2010). Implementasi LMS-Moodle pada Universitas tersebut belum pernah dilakukan pengukuran atas self-efficacy, sikap, kepuasan dan niat perilaku pengguna LMS-Moodle dan sejauhmana pengguna menilai aksesibilitas sistem yang ada.

Riset ini menguji faktor-faktor yang mempengaruhi sikap, kepuasan dan niat untuk menggunakan e-learning pada mahasiswa dengan memasukkan karakteristik pengguna, karakteristik sosial dan karakteristik organisasi pada sebuah universitas. Riset ini mengadopsi penelitian yang dilakukan oleh Park (2009) dan Pérez et al., (2013). Penelitian ini diharapkan dapat memberikan kontribusi terhadap tambahan literatur mengenai self-efficacy, sikap, aksesibilitas sistem, kepuasan dan niat menggunakan dalam konteks e-learning, dan juga memberikan manfaat dan masukan kepada dunia pendidikan yang hendak mengadopsi e-learning dalam kegiatan pembelajarannya di masa yang akan datang.

\section{KAJIAN PUSTAKA DAN PERUMUSAN HIPOTESIS}

\section{Self-efficacy}

Konsep afikasi diri berasal dari teori kognitif sosial. Self-efficacy adalah kepercayaan seseorang akan kemampuannya untuk mengatur dan melakukan tindakan 
yang diperlukan untuk mengelola situasi tertentu (Bandura 1977). Park (2009) mendefinisikan self-efficacy sebagai perwakilan dari kepercayaan diri seseorang dalam menemukan informasi dan berkomunikasi dengan instruktur pada sistem $e$ learning dan keterampilan yang diperlukan untuk menggunakan sistem tersebut. Selfefficacy tidak hanya mengukur keterampilan individu tetapi juga mencerminkan keyakinan seseorang bahwa ia dapat mencapai tindakan tertentu saat ini atau dimasa depan dengan keterampilan yang dimilikinya (Kim dan Kim 2005). Keyakinan efikasi diri memainkan peranan penting dalam pengaturan diri terhadap motivasi mengenai tantangan yang hendak diraih dan harapan dari hasil yang hendak dicapai. Dengan kata lain, seseorang akan memilih tantangan yang akan diambilnya, berapa banyak usaha yang akan dikeluarkan, berapa lama untuk bertahan dalam menghadapi rintangan dan kegagalan, dan apakah kegagalan tersebut menjadi motivasi atau demoralisasi, semuanya didasarkan akan keyakinan afikasi (Bandura 2001).

Sawang et al., (2013) menyatakan bahwa salah satu kunci utama keberhasilan penerapan e-learning berhubungan dengan karakteristik individu atau pelajar, yaitu berhubungan dengan self-efficacy dari pelajar. Self-efficacy penting untuk membangun motivasi yang dapat mempengaruhi pilihan, tujuan, reaksi emosional, usaha, menghadapi sesuatu dan ketekunan seseorang. Seseorang dengan tingkat self-efficacy yang lebih tinggi lebih terjamin dalam kemampuan dan lebih dipercaya untuk menyelesaikan tugas tertentu. Mereka juga memiliki komitmen yang lebih besar dalam mencapai tujuan dan melihat kesulitan sebagai tantangan. Sebaliknya, orang dengan tingkat self-efficacy yang rendah cenderung lebih mudah kehilangan kepercayaan akan kemampuannya dalam menyelesaikan tugas, memiliki inspirasi yang rendah, dan lemah dalam komitmen untuk mencapai tujuannya (Bratkovič et al., (2017). Pada penelitian ini menggunakan definisi self-efficacy dari Park (2009).

\section{Subjective Norm}

Norma subjektif adalah norma yang dipengaruhi oleh sosial (Yau dan Ho 2015). Norma subjektif merupakan konsep yang berhubungan dengan perilaku dan konteks sosial (Venkatesh dan Davis 2000). Norma subjektif mengungkapkan keyakinan seseorang mengenai bagaimana ia akan dilihat oleh kelompok referensinya jika ia melakukan perilaku tertentu (Al-swidi et al., 2014). Konsep ini menekankan pentingnya dampak sosial terhadap keputusan seseorang untuk melakukan perilaku tertentu (Venkatesh dan Davis 2000).

Ajzen dan Fishbein (1975) mendefinisikan subjective norm sebagai persepsi seseorang tentang pemikiran orang lain yang akan mendukung atau tidak mendukungnya dalam melakukan sesuatu. Sedangkan menurut Meyer dan Allen, (1997), norma subjektif adalah perilaku tanggap atas tekanan dari masyarakat, budaya, keluarga dan kelompok referensi dapat mempengaruhi perilaku individu untuk mematuhi perilaku tertentu. Pada penelitian ini menggunakan definisi norma subjektif dari Meyer dan Allen (1997). 


\section{Akses Terhadap Sistem}

Istilah sistem banyak digunakan dalam berbagai bentuk, seperti sebagai sistem operasi jika dihubungkan dengan software, menjadi komputer jika dihubungkan dengan perangkat keras dan sebagai sistem jaringan jika dihubungkan dengan perangkat keras, perangkat lunak dan kabel (Laskowski et al., 2004). Aksesibilitas yang dirasakan merupakan faktor penting yang mempengaruhi kegunaan dan keberhasilan sistem informasi (Rice dan Shook 1988).

Aksesibilitas dapat didefinisikan sejauh mana sistem dan informasi yang ada dapat diakses dengan usaha yang relatif rendah (Miller dan Doyle 1987). Sedangkan menurut Laskowski et al., (2004), aksesibilitas didefinisikan sebagai karakteristik yang dapat diukur; sejauh mana sistem tersebut tersedia dan dapat digunakan oleh individu yang tidak mampu. CEN/CENELEC/ETSI (2014) mendefinisikan aksesibilitas sebagai sejauh mana produk, sistem, layanan lingkungan dan fasilitas dapat digunakan oleh orang-orang dari populasi dengan karakteristik jangkauan terluas dan kemampuan untuk mencapai tujuan dan konteks tertentu. Dalam bidang teknologi, agar dapat diakses, sistem tersebut harus mendukung pencapaian pekerjaan dan dapat digunakan oleh masing-masing individu sesuai dengan yang diinginkan pengguna (Fourney dan Cartera 2006). Dalam konteks dengan aksesibilitas dari sistem $e$ learning, maka e-learning system accessibility dapat didefinisikan sebagai sejauh mana tingkat kemudahan seorang mahasiswa dalam mengakses dan mengunakan sistem e-learning kampus sebagai faktor organisasi (Park 2009). Pada penelitian ini menggunakan definisi aksesibilitas sistem dari Park (2009).

\section{Sikap}

Sikap telah lama dikenal sebagai konstruk yang memandu perilaku masa depan atau penyebab niat yang pada akhirnya mengarah pada perilaku tertentu (Gopi dan Ramayah 2007). Sikap adalah kecenderungan yang dipelajari untuk merespon secara konsisten dengan cara baik atau tidak baik sehubungan dengan objek tertentu (Ajzen dan Fishbein 1975). Theory of Reasoned Action (TRA) menyatakan sikap mengacu pada efek evaluatif dari perasaan positif atau negatif seseorang dalam melakukan perilaku tertentu (Ajzen dan Fishbein 1975). Ajzen dan Fishbein (2000) mendefinisikan sikap sebagai sejauh mana perasaan baik atau kurang baik seseorang terhadap objek psikologis. Sedangkan menurut Sun et al., (2007), sikap adalah kesan dari pelajar yang berpartisipasi dalam kegiatan e-learning melalui penggunaan komputer. Dalam penelitian ini menggunakan definisi sikap dari Sun et al., (2007).

Sikap dibentuk dan dibangun dari nilai dan kepercayaan (Verplanken dan Holland 2002). Sikap seseorang akan mengacu pada predisposisi umum terhadap perilaku tertentu dan merupakan hasil dari keyakinannya mengenai mengenai perilaku tertentu dan melekat pada keyakinannya (Pérez, Mafe, and Blas 2013). Seseorang bisa saja mempunyai beberapa keyakinan terhadap objek tertentu dan pada gilirannya keyakinan dan evaluasi tersebut membentuk suatu sikap. Selain itu, sikap juga 
merupakan faktor kunci dalam menganalisa perilaku adopsi teknologi (Kuo dan Yen 2009). Penelitian sebelumnya menemukan bahwa sikap individu dipengaruhi oleh berbagai variabel seperti pelatihan, dokumentasi, fitur-fitur yang terdapat dalam sistem, dan dukungan bagi pengguna (Lucas dan Spitler 1999).

\section{Kepuasan}

Menurut Oliver (1980), kepuasan pengguna dapat didefinisikan sebagai evaluasi seseorang dari perbedaan antara harapan sebelumnya dengan hasil akhir. Jika kinerja yang dirasakan sesuai atau lebih dari harapan pelanggan, maka mereka akan puas. Demikian juga sebaliknya, apabila kinerja yang dirasakan tidak sesuai atau lebih rendah dari harapan, maka mereka akan menjadi tidak puas (Fullerton dan Taylor 2015). Pada konteks lingkungan virtual, kepuasan dapat didefinisikan sebagai kepuasan pengguna sehubungan dengan pengalaman online sebelumnya (Anderson dan Srinivasan 2003). Mckinney et al., (2002) menyatakan bahwa kepuasan elektronik dalam konteks pembelian tiket pesawat melalui situs adalah sejauhmana pengguna percaya bahwa pengalaman mereka dalam situs tiket pesawat tersebut tersedia dan memenuhi harapan dan persyaratan mereka. Kepuasan dapat digunakan sebagai indikator kunci apakah pengguna akan menggunakan atau mengadopsi sistem $e$ learning lebih lanjut (Arbaugh 2000). Penelitian ini menganalisis kepuasan pengguna dalam konteks penggunaan e-learning.

\section{Niat untuk Menggunakan Sistem Manajemen e-learning}

Niat adalah pernyataan pikiran dari perhatian seseorang terhadap objek tertentu atau jalur dalam mencapai sesuatu (Vesalainen dan Pihkala 1999). Semakin kuat sebuah niat, maka semakin tinggi kemungkinan seseorang terlibat dalam perilaku tersebut (Foong dan Khoo 2015). Niat untuk menggunakan adalah proses pengambilan keputusan psikologis. Hal ini dikarenakan ketika pengguna memiliki kebutuhan, maka ia akan termotivasi untuk memenuhi kebutuhan tersebut dengan mencari informasi yang sesuai dengan pengalaman dan lingkungan eksternalnya, melakukan evaluasi, mempertimbangkan semua infomasi, dan kemudian memutuskan untuk menggunakan produk tersebut setelah membandingkan dan menilai alternatif yang ada (Engel et al., 1995). Mayer et al., (1995) menyatakan bahwa, niat untuk menggunakan didefinisikan sebagai sejauh mana pengguna berniat untuk menggunakan teknologi tersebut di masa depan. Pada penelitian ini niat untuk menggunakan didefinisikan sebagai sejauh mana niat pelajar untuk menggunakan sistem manajemen e-learning.

\section{Hubungan antara e-learning Self-efficacy, Attitude, dan Niat untuk Menggunakan E-Learning}

Bandura (1997) menyatakan bahwa self-efficacy merupakan faktor yang penting dalam menentukan bagaimana efektifitas karyawan untuk mengadopsi sebuah teknologi. Semakin individu tersebut memiliki sel-efficacy yang tinggi maka semakin baik dan cepat mengadopsi teknologi tersebut dan demikian juga sebaliknya. Adesina dan Ayo (2010) menyatakan bahwa penelitian tentang hubungan antara self-efficacy 
dan sikap masih sangat sedikit. Hasil penelitian yang dilakukan oleh Adesina dan Ayo (2010) terhadap pengguna e-banking di Nigeria menemukan bahwa self-efficacy berpengaruh terhadap sikap. Hasil berbeda didapatkan dari penelitian yang dilakukan oleh Park (2009) terhadap mahasiswa di Korea Selatan dan Ayo et al., (2016) di Nigeria, yang menyatakan bahwa self-efficacy tidak berpengaruh terhadap sikap.

Selain sikap, self-efficacy juga diyakini memiliki pengaruh terhadap niat untuk menggunakan. Ketika seseorang merasa bahwa ia memiliki kepercayaan diri bahwa ia mampu untuk melakukan atau menggunakan sesuatu, maka ia akan memiliki niat untuk menggunakannya. Hal ini didukung oleh penelitian yang dilakukan oleh Park (2009); Van Acker et al., (2013), Liaw et al., (2007) dan Bashir dan Madhavaiah (2014) pada industri perbankan di India. Oleh karena itu, penelitian ini berpendapat bahwa kemampuan individu untuk berhasil menggunakan sistem e-learning akan mempengaruhi sikapnya terhadap penggunaan e-learning dan kemampuaan individu agar berhasil menggunakan sistem e-learning akan mempengaruhi niatnya untuk $e$ learning. Untuk menentukan faktor-faktor yang berdampak pada sikap terhadap penggunaan e-learning dan memvalidasi hubungan antara self-efficacy, sikap dan niat, maka diusulkan hipotesis satu dan hipotesis dua sebagai berikut.

H1: e-learning self-efficacy berpengaruh terhadap e-learning attitude.

H2: -learning self-efficacy berpengaruh terhadap niat untuk menggunakan $e$ learning.

\section{Hubungan antara Subjective Norm, Attitude dan Niat untuk Menggunakan E- Learning}

Ketika norma subjektif yang diyakini oleh individu diterima oleh masyarakat, maka hal tersebut akan mempengaruhi sikap penerimaan dari individu tersebut. Hal ini juga berlaku bagi penggunaan atau adopsi terhadap teknologi. Ketika seseorang merasa bahwa teknologi yang ada sesuai dengan norma subjektif maka ia akan memiliki sikap positif dan bersedia untuk mempelajari teknologi tersebut. Beberapa penelitian terdahulu menemukan bahwa norma subjektif memiliki pengaruh positif terhadap sikap. Seperti penelitian yang dilakukan oleh Al-swidi et al., (2014) terhadap 184 mahasiswa di Pakistan, penelitian yang dilakukan oleh Shittu et al., (2011) terhadap 150 mahasiswa di Malaysia, dan penelitian Kim et al., (2013) di Korea Selatan.

Selain itu, keyakinan terhadap sesuatu jika didukung oleh norma subjektif, maka juga dapat mempengaruhi niat menggunakan seseorang. Ketika seseorang yakin bahwa menggunakan suatu teknologi didukung oleh norma subjektif, maka mereka cenderung memiliki niat untuk menggunakan karena meyakini bahwa penggunaan tersebut tidak melanggar norma subjektif yang ada. Hal ini didukung oleh penelitian 
yang dilakukan oleh Grandon et al., (2005), penelitian yang dilakukan oleh Van Acker et al., (2013), Park (2009), Teng dan Wang (2015) pada industri makanan organik, penelitian yang dilakukan oleh Bashir dan Madhavaiah (2014) pada industri perbankan di India yang menyatakan bahwa pengaruh sosial berpengaruh positif terhadap niat untuk menggunakan dan Sanakulov dan Karjaluoto (2015) yang menyatakan bahwa norma subjektif berpengaruh terhadap behavioral intention. Akan tetapi hal sebaliknya ditemukan pada penelitian Ndubisi (2006) dan penelitian yang dilakukan oleh Kim et $a l$. , (2013) terhadap industri makanan di Korea Selatan. Oleh karena itu, penelitian ini berpendapat bahwa norma subjektif yang diyakini oleh individu terhadap e-learning mempengaruhi sikapnya terhadap penggunaan e-learning dan norma subjektif yang diyakini individu terhadap sistem e-learning juga akan mempengaruhi niatnya untuk menggunakan e-learning. Untuk menentukan faktor-faktor yang berdampak pada sikap terhadap penggunaan e-learning dan memvalidasi hubungan antara subjective norm, sikap dan niat, maka diusulkan hipotesis tiga dan hipotesis empat sebagai berikut.

H3: Subjective norm berpengaruh terhadap e-learning attitude.

H4: Subjective norm berpengaruh terhadap niat untuk menggunakan $e$ learning.

\section{Hubungan antara Sistem Accessibility, Attitude, dan Niat untuk Menggunakan}

Dukungan organisasi bagi penerapan e-learning sangat dibutuhkan agar tercapainya keberhasilan dan kepuasan pelajar dalam menggunakan e-learning. Dukungan organisasi yang cukup akan membantu individu untuk menjadi lebih nyaman dengan sistem dan software yang ada, dimana akan mengacu pada kepuasan pelajar dengan sistem e-learning tersebut (Sawang, Newton, and Jamieson 2013). Dukungan organsisasi dapat berupa kemudahan akses atau dengan kata lain tidak adanya kesulitan pengguna dalam hal ini pelajar untuk mengakses sistem tersebut. Tersedianya akses yang baik terhadap sistem akan menghasilkan sikap positif pengguna e-learning yang pada akhirnya akan meningkatkan niat untuk menggunakan sistem tersebut. Hal ini didukung oleh penelitian yang dilakukan oleh Aarons et al., (2009), hasil penelitiannya menunjukkan bahwa dukungan organisasi berpengaruh positif terhadap sikap dan menurut penelitian Alavi dan Abdollahipour (2014) terhadap mahasiswa di Iran menemukan bahwa aksesibilitas berpengaruh terhadap sikap. Abedalaziz et al., (2013) menyatakan bahwa sikap positif terhadap komputer dan internet dipengaruhi oleh ketersediaan dan aksesibilitas yang diberikan oleh universitas. Hasil penelitian Teng dan Wang (2015) pada industri makanan di Taiwan menemukan bahwa aksesibilitas akan mempengaruhi behavioral intention. Hasil penelitian yang dilakukan oleh Park (2009) menyatakan bahwa akses terhadap sistem tidak berpengaruh terhadap sikap dan niat untuk menggunakan. Penelitian ini 
berpendapat bahwa tersedianya akses sistem e-learning mempengaruhi sikapnya terhadap penggunaan e-learning dan tersedianya akses sistem e-learning mempengaruhi niatnya untuk menggunakan e-learning. Untuk menentukan faktorfaktor aksesibilitas sistem yang berdampak pada sikap dan niat untuk menggunakan $e$ learning dan memvalidasi hubungan antara aksesibilitas sistem, sikap dan niat, maka diusulkan hipotesis lima dan hipotesis enam sebagai berikut.

H5: Sistem accessibility berpengaruh terhadap e-learning attitude.

H6: Sistem accessibility berpengaruh terhadap niat untuk menggunakan $e$ learning.

\section{Hubungan antara e-learning Attitude dan e-satisfaction}

Apabila sesorang memiliki sikap positif terhadap sesuatu maka akan menyebabkan seseorang tersebut menjadi puas. Hal ini didukung oleh penelitian yang dilakukan oleh Ozkan et al., (2009); Sun et al., (2007) terhadap 295 mahasiswa di Taiwan dan Pérez et al., (2013) terhadap pengguna media sosial di Spanyol. Dengan demikian dapat disimpulkan bahwa sikap individu terhadap sistem e-learning mempengaruhi kepuasannya terhadap penggunaan e-learning. Untuk menentukan faktor-faktor yang berdampak pada kepuasan dan memvalidasi hubungan antara sikap dan kepuasan, maka diusulkan hipotesis tujuh sebagai berikut.

H7: E-learning attitude berpengaruh terhadap e-satisfaction.

\section{Hubungan antara $e$-satisfaction dan Intention to Use}

Penelitian yang dilakukan oleh Liaw (2008) menemukan bahwa terdapat pengaruh antara kepuasan dan niat untuk menggunakan. Hal ini juga didukung oleh Chang et al., (2011); Ryu et al., (2012) dan Loureiro et al., (2014) terhadap pengguna online banking di Portugal dan Austria. Penelitian ini berpendapat bahwa kepuasan individu terhadap sistem e-learning mempengaruhi niatnya untuk menggunakan $e$ learning. Untuk menentukan faktor-faktor yang berdampak pada niat untuk menggunakan dan memvalidasi hubungan antara kepuasan dan niat untuk menggunakan, maka diusulkan hipotesis delapan sebagai berikut.

H8: e-satisfaction berpengaruh terhadap intention to use 


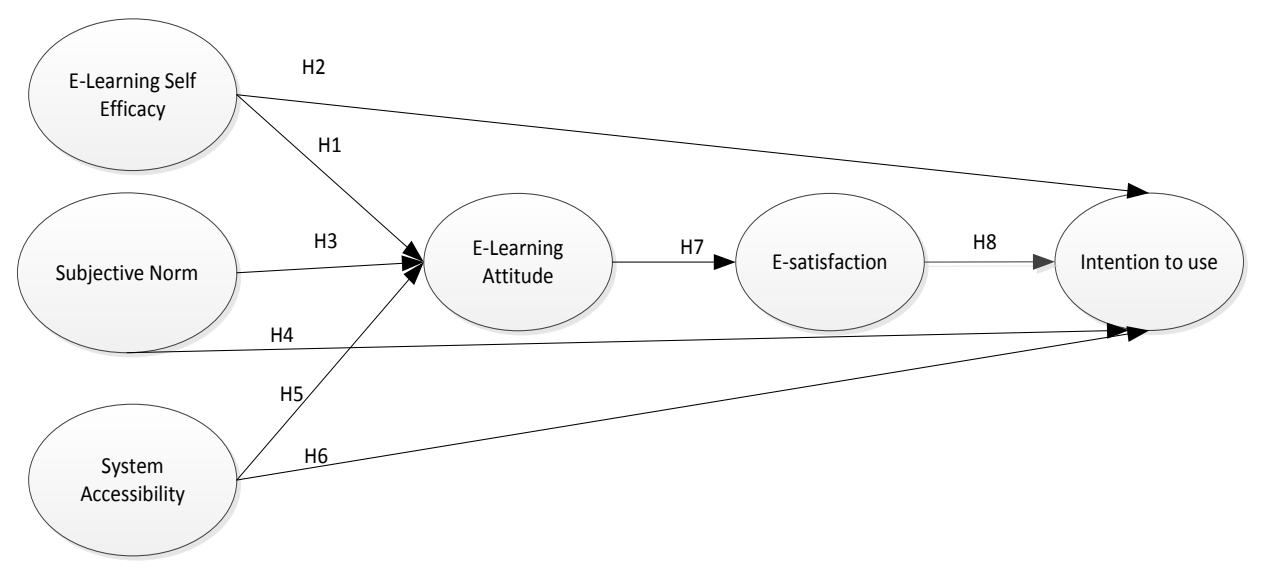

Sumber: Park (2009) dan Pérez et al., (2013)

\section{Gambar 1}

Model Konseptual

\section{METODA PENELITIAN}

Populasi dalam penelitian ini adalah mahasiswa S1 pada sebuah universitas yang pernah menggunakan sistem manajemen e-learning atau LMS-Moodle. Pengambilan sampel dilakukan dengan penyebaran kuesioner terhadap 400 mahasiswa dan kuesioner yang kembali sebanyak 232. Hasil seleksi purposive sampling atas penggunaan e-learning terdapat 89 mahasiswa belum pernah menggunakan, dan 43 kuesioner tidak lengkap. Hasil akhir seleksi menunjukkan terdapat100 kuesioner yang dapat digunakan.

Terdapat enam variabel dalam penelitian ini yaitu variabel self-efficacy, norma subjektif, akses terhadap sistem, sikap pengguna, kepuasan dan niat untuk menggunakan. Konstruk self-efficacy terdiri dari lima indikator yang diadopsi dari Liaw (2008) dan Park (2009). Variabel dari norma subjektif terdiri dari empat indikator yang diadopsi dari Park (2009). Variabel akses terhadap sistem terdiri dari dua indikator yang diadopsi dari Park (2009). Variabel sikap pengguna terdiri dari tiga indikator yang diadopsi dari Park (2009). Variabel kepuasan terdiri dari lima empat indikator yang diadopsi dari Liaw (2008). Variabel niat untuk menggunakan terdiri dari dua indikator yang diadopsi dari Liaw (2008). Semua pertanyaan yang ada menggunakan 5 skala likert dari sangat tidak setuju (1) sampai sangat setuju (5).

Model pengukuran (outer model) pada penelitian ini digunakan untuk menguji validitas konstruk dan reliabilitas instrumen. Convergent validity dari model pengukuran dianggap valid apabila memiliki nilai AVE $>0,5$ dan faktor loading $>0,70$. Pada uji reliabilitas, suatu item pertanyaan dianggap reliabel apabila memiliki 
cronbach's alpha >0,7 dan nilai composite reliability >0,7 (Latan dan Ghozali 2012). Pengujian hipotesis dilakukan dengan menggunakan analisis Partial Least Square (PLS) dengan menggunakan program Smart PLS 3.0.

\section{ANALISIS DAN PEMBAHASAN}

Profil responden pada penelitian ini dapat dilihat pada Tabel 1. Semua responden dalam penelitian ini pernah menggunakan e-learning dalam hal ini Moodle.

Tabel 1

Profil Responden

\begin{tabular}{lcc}
\hline Pernyataaan & Total & Percentage (\%) \\
\hline Gender & 48 & 48 \\
Pria & 52 & 52 \\
Wanita & 4 & 4 \\
Usia & 77 & 77 \\
18 tahun & 18 & 18 \\
$20-22$ tahun & 1 & 1 \\
$>23$ tahun & & \\
Mahasiswa angkatan : & 62 & 62 \\
2016 & 23 & 23 \\
2015 & 12 & 12 \\
2014 & 3 & 3 \\
Lainnya. & 100 & 100 \\
Pernah menggunakan Moodle & 0 & 0 \\
Ya & & \\
Tidak pernah & & \\
Jumlah Mata kuliah yang menggunakan Moodle dalam semester & 28 \\
ini & 28 & 16 \\
1 Mata kuliah & 16 & 54 \\
3 Mata kuliah & 54 & \\
$>4$ Mata kuliah & 2 & \\
\hline Sumber: Hasil pengolahan data SPSS (2017) & &
\end{tabular}

Pada pengujian validitas, terdapat satu item dari variabel norma subjektif yang memiliki nilai outer loading di bawah 0,7 yaitu sebesar 0,57 , sehingga item tersebut dihilangkan. Setelah itu dilakukan pengujian validitas ulang. Setelah dilakukan pengujian validitas ulang, semua indikator memiliki nilai outer loading di atas 0,7 sehingga dapat dikatakan bahwa semua item dinyatakan valid. Hal ini dapat dilihat pada Tabel 2. Selanjutnya dilakukan pengujiian reliabilitas. Pada pengujian reliabilitas dapat dilihat bahwa semua konstruk memiliki nilai average variance extracted (AVE) lebih besar dari 0,5 yaitu mulai dari 0,74 hingga 0,97 , sedangkan nilai composite reliability $(C R)$ untuk setiap konstruk mulai dari 0,89 hingga 0,98 . Nilai minimal yang harus dipenuhi untuk average variance extracted adalah $>0,5$ dan composite reliability $>0,70$. Sehingga dapat disimpulkan bahwa konstruk yang ada reliabel.

Pengujian validitas diskriminan dapat dilihat pada Tabel 3. Suatu konstruk dikatakan memiliki validitas diskriminan yang baik apabila memiliki nilai > 0,7. 
Berdasarkan tabel dibawah, dapat dikatakan bahwa semua konstruk memiliki nilai validitas deskriminan yang baik.

Tabel 3

Validitas Diskriminan

\begin{tabular}{|c|c|c|c|c|c|c|}
\hline & Sikap & Niat & $\begin{array}{c}\text { Akesibilitas } \\
\text { sistem }\end{array}$ & $\begin{array}{c}\text { Self- } \\
\text { Efficacy }\end{array}$ & $\begin{array}{c}\text { Norma } \\
\text { Subjektif }\end{array}$ & Kepuasan \\
\hline Sikap & $\mathbf{0 , 8 9}$ & & & & & \\
\hline $\begin{array}{l}\text { Niat untuk } \\
\text { menggunakan }\end{array}$ & 0,42 & 0,91 & & & & \\
\hline $\begin{array}{l}\text { Akesibilitas } \\
\text { sistem }\end{array}$ & 0,11 & 0,23 & $\mathbf{0 , 8 9}$ & & & \\
\hline Self-Efficacy & 0,32 & 0,41 & 0,36 & $\mathbf{0 , 8 7}$ & & \\
\hline Norma Subjektif & 0,51 & 0,51 & 0,18 & 0,56 & $\mathbf{0 , 8 6}$ & \\
\hline Kepuasan & 0,51 & 0,45 & 0,31 & 0,5 & 0,4 & 0,94 \\
\hline
\end{tabular}

Sumber: Hasil pengolahan data PLS (2017)

Hasil pengujian hipotesis pada penelitian ini dapat dilihat pada Tabel 4 . Terdapat empat hipotesis yang tidak signifikan karena $p$ value lebih besar dari 0,05 yaitu self-efficacy tidak berpengaruh terhadap sikap (H1), self-efficacy tidak berpengaruh terhadap niat untuk menggunakan (H2), aksesibilitas sistem tidak berpengaruh terhadap sikap (H5), dan aksesibilitas sistem tidak berpengaruh terhadap niat untuk menggunakan (H6). Keempat hipotesis lainnya signifikan karena $p$ value lebih kecil 0,05.

Tabel 4

Hasil Pengujian

\begin{tabular}{clcc}
\hline Hypothesis & \multicolumn{1}{c}{ Path } & P value & Result \\
\hline $\mathrm{H}_{1}$ & $\begin{array}{l}\text { Self-efficacy } \rightarrow \text { sikap } \\
\text { Self-efficacy } \rightarrow \text { niat untuk }\end{array}$ & 0,65 & Tidak Signifikan \\
$\mathrm{H}_{2}$ & $\begin{array}{l}\text { menggunakan } \\
\text { Norma Subjektif } \rightarrow \text { sikap }\end{array}$ & 0,00 & Tidak signifikan \\
$\mathrm{H}_{3}$ & $\begin{array}{l}\text { Norma Subjektif } \\
\mathrm{H}_{4}\end{array}$ & 0,00 & Signifikan \\
& $\rightarrow$ niat untuk menggunakan & 1,00 & Signifikan \\
$\mathrm{H}_{5}$ & Sistem accessibility $\rightarrow$ sikap & Tidak signifikan \\
$\mathrm{H}_{6}$ & Sistem accessibility $\rightarrow$ niat untuk & 0,47 & Tidak Signifikan \\
& menggunakan & & \\
$\mathrm{H}_{7}$ & Sikap $\rightarrow$ kepuasan & 0,00 & Signifikan \\
$\mathrm{H}_{8}$ & Kepuasan $\rightarrow$ niat untuk menggunakan & 0,02 & Signifikan \\
\hline
\end{tabular}

Sumber: Hasil pengolahan data dengan PLS, 2017

Hasil pengujian hipotesis pertama menunjukkan bahwa self-efficacy tidak berpengaruh terhadap sikap. Hasil pengujian ini konsisten dengan hasil penelitian yang dilakukan oleh Park (2009) terhadap mahasiswa yang menggunaan e-learning di Korea Selatan dan penelitian yang dilakukan oleh Ayo et al., (2016) di Nigeria. Berdasarkan nilai rata-rata dari self-efficacy menunjukkan bahwa responden memiliki rasa percaya diri yang cukup tinggi dalam menggunakan, mengoperasikan dan mencari informasi pada e-learning dan juga memiliki keterampilan yang dibutuhkan dalam menggunakan sistem e-learning ini. Nilai rata-rata dari sikap menunjukkan bahwa mereka memiliki sikap yang positif terhadap e-learning. Alasan penolakan hipotesis 
ini diduga walaupun mahasiswa memiliki kemampuan dan keterampilan untuk menggunakan e-learning akan tetapi tidak mempengaruhi sikap mereka terhadap $e$ learning. Hal ini dapat saja disebabkan karena mereka diwajibkan untuk menggunakan e-learning agar dapat mengakses material perkuliah dan mengirimkan tugas melalui e-learning.

Hasil pengujian hipotesis kedua menunjukkan bahwa self-efficacy tidak berpengaruh terhadap niat untuk menggunakan e-learning. Sehingga hipotesis kedua tidak didukung. Nilai rata-rata self-efficacy dari hasil penelitian ini menunjukkan bahwa mahasiswa yang menjadi responden memiliki kemampuan dan keterampilan yang diperlukan untuk menggunakan Moodle. Nilai rata-rata dari niat untuk menggunakan e-learning memiliki nilai yang cukup rendah yaitu sebesar 3,410 dan 3,130. Hal ini menunjukkan bahwa walaupun mahasiswa memiliki kemampuan dan keterampilan, akan tetapi hal ini tidak membuat mereka memiliki niat untuk menggunakan secara maksimal terhadap e-learning tersebut. Niat mereka untuk menggunakan e-learning hanya sebatas pada pemenuhan persyaratan perkuliahan dan mengirimkan tugas. Mereka tidak berniat untuk menjadi pengguna secara optimal sistem e-learning tersebut dan tidak terlalu berniat untuk mengecek pengumuman dari sistem e-learning secara regular. Kemungkinan mereka hanya membuka sistem $e$ learning ini ketika diberitahukan bahwa ada materi yang harus dipelajari dan dibaca sebelum kelas dimulai dan hanya sebatas untuk mengumpulkan tugas.

Hasil pengujian hipotesis ketiga menunjukan bahwa norma subjektif berpengaruh terhadap sikap. Hasil nilai rata-rata dari norma subjektif menunjukkan bahwa mahasiswa menganggap penggunaan e-learning ini sesuai dengan norma sosial dan nilai-nilai yang ada dan mereka sebagai mahasiswa merasa penting untuk menggunakan e-learning tersebut. Hasil pengujian hipotesis ketiga ini sesuai dengan penelitian sebelumnya terhadap mahasiswa di Pakistan dan di Malaysia (Al-swidi et al., (2014); Shittu et al., (2011). Ketika mahasiswa meyakini bahwa penggunaan $e$ learning sesuai dengan nilai dan norma sosial yang ada, maka sikap mereka terhadap e-learning juga menjadi positif.

Hipotesis keempat menunjukkan bahwa norma subjektif berpengaruh terhadap niat untuk menggunakan. Hasil penelitian ini sesuai dengan penelitian yang dilakukan oleh Grandon et al., (2005) dan Park (2009). Sehingga dapat dikatakan, mahasiswa merasa bahwa menggunakan e-learning sebagai proses pembelajaran sesuai dengan norma sosial dan nilai yang ada, maka mereka memiliki niat perilaku untuk menggunakan e-learning tersebut karena meyakini penggunaan e-learning ini tidak melanggar norma yang ada.

Hipotesis kelima menyatakan bahwa aksesibilitas sistem berpengaruh terhadap sikap. Akan tetapi menurut hasil pengujian pada penelitian ini didapatkan bahwa aksesibilitas sistem tidak berpengaruh terhadap sikap, sehingga hipotesis kelima tidak didukung. Hasil penelitian ini juga didukung oleh penelitian sebelumnya yang 
dilakukan oleh Park (2009) terhadap mahasiswa di Korea Selatan. Nilai rata-rata aksesibilitas sistem pada penelitian ini cukup baik dan 84 persen responden mengatakan bahwa aksesibilitas sistem tidak menjadi kendala bagi mahasiswa untuk menggunakan e-learning. Faktor organisasi dalam ketersediaan akses terhadap sistem e-learning tidak mempengaruhi sikap mereka terhadap e-learning.

Hipotesis keenam menunjukan bahwa aksesibilitas sistem tidak berpengaruh terhadap niat untuk menggunakan e-learning. Hasil penelitian ini didukung oleh penelitian sebelumnya (Park 2009). Akses terhadap sistem yang disediakan oleh universitas sudah cukup baik, dengan melihat 84 persen responden menyatakan bahwa mereka tidak menghadapi kesulitan dalam mengakses sistem. Jikalau pun aksesibilitas sistem yang disediakan oleh universitas tidak baik, mahasiswa tetap berniat untuk menggunakan sistem e-learning. Hal ini dapat disebabkan karena mahasiswa diharuskan untuk menggunakan e-learning untuk memenuhi tugas belajarnya. Sehingga mereka harus mencari cara bagaimana agar tugasnya dapat diselesaikan dengan baik walaupun jika mereka menghadapi kesulitan dan dapat bertanya kepada teman lainnya jika menghadapi kesulitan dalam mengakses sistem tersebut.

Hasil pengujian hipotesis ketujuh menyatakan bahwa sikap berpengaruh terhadap kepuasan e-learning. Hal ini didukung oleh penelitian sebelumnya yang dilakukan oleh Ozkan et al., (2009) dan Sun et al., (2007). Hal ini menunjukkan bahwa ketika mahasiswa memiliki sikap yang positif terhadap sistem e-learning ini maka mereka akan menjadi puas.

Hipotesis terakhir menemukan bahwa kepuasan berpengaruh terhadap niat untuk menggunakan. Hasil ini sejalan dengan penelitian sebelumnya yang dilakukan oleh Whittaker et al., (2007), Liaw (2008) dan Ranaweera et al., (2008). Mahasiswa yang puas menggunakan sistem e-learning ini akan memiliki niat untuk menggunakan sistem tersebut.

\section{SIMPULAN, KETERBATASAN DAN SARAN}

Berdasarkan hasil analisis dan pengolahan data, maka beberapa kesimpulan yang dapat ditarik dalam penelitian ini adalah self-efficacy tidak berpengaruh terhadap sikap dan niat untuk menggunakan e-learning. Norma subjektif berpengaruh terhadap sikap dan niat untuk menggunakan e-learning. Aksesibilitas sistem tidak berpengaruh terhadap sikap dan niat untuk menggunakan e-learning. Sikap berpengaruh terhadap kepuasan dan e-satisfaction berpengaruh terhadap niat untuk menggunakan. Implikasi teoritis pada penelitian ini adalah menambah literatur bagi perkembangan ilmu dan penelitian berikutnya mengenai self-efficacy, norma subjektif, system accessibility, sikap dan kepuasan.

Pada penelitian ini memberi kontribusi teoritis bahwa self-efficacy dan aksesibilitas sistem tidak berpengaruh terhadap sikap dan niat untuk menggunakan $e$ - 
learning. Sedangkan implikasi manajerial dari penelitian ini adalah memberikan masukan kepada universitas yang mengimplementasikan sistem manajemen $e$ learning bahwa sistem e-learning sesuai dengan norma dan nilai lokal, sehingga bagi universitas yang ingin melaksakan sistem ini tidak perlu khawatir bahwa penerapan sistem ini bertentangan dengan norma dan nilai yang ada. Universitas yang menyediakan sistem e-learning kepada mahasiswa adalah sangat baik dan diberikan kemudahan dalam mengakses sistem. Hal tersebut tidak mempengaruhi sikap dan niat untuk menggunakan e-learning secara sukarela karena adanya kewajiban dari dosen yang memaksa mahasiswa menggunakan dan mengirimkan tugasnya melalui $e$ learning. Mereka akan mencari cara untuk mengakses sistem tersebut mengingat bahwa lokasi universitas pada penelitian ini adalah berlokasi di perkotaan yang kebanyakan semua tempat menyediakan layanan internet dan akses terhadap internet. Mungkin saja akan diperoleh hasil yang berbeda apabila penelitian dilakukan di daerah yang memiliki keterbasan akses internet.

Keterbatasan dalam penelitian ini adalah jumlah responden yang digunakan dalam penelitian ini memiliki jumlah yang terbatas. Keterbatasan yang kedua adalah responden dari penelitian ini adalah pengguna e-learning yaitu mahasiswa, sehingga hanya melihat unsur dari pengguna dan tidak melihat pandangan dari pengajarnya.

Saran untuk penelitian berikutnya adalah meneliti persepsi kegunaan yang dirasakan dan persepsi kemudahan penggunaannya untuk mengetahui sejauh mana mahasiswa atau pengguna e-learning merasakan manfaat dan kemudahan sistem elearning. Riset dapat difokuskan untuk menguji optimalisasi penggunaan dan implementasi sistem ini. Saran kedua, riset dapat difokuskan dari aspek pengajar sebagai responden karena pengajar juga memiliki kontribusi dalam keberhasilan suatu implementasi sistem manajemen e-learning. Saran terakhir adalah melakukan penelitian terhadap pengguna e-learning di kota kecil untuk melihat bagaimana pengaruh akesibilitas sistem terhadap sikap dan niat menggunakan $e$-learning.

\section{DAFTAR PUSTAKA}

Aarons, Gregory A, David H Sommerfeld, and Christine M Walrath-Greene. 2009. "Evidence-Based Practice Implementation: The Impact of Public versus Private Sector Organization Type on Organizational Support, Provider Attitudes, and Adoption of Evidence-Based Practice." Implementation Science 4 (1). BioMed Central:83.

Abedalaziz, Nabeel, Shahrir Jamaluddin, and Chin Hai Leng. 2013. "Measuring Attitudes toward Computer and Internet Usage among Postgraduate Students in Malaysia." Turkish Online Journal of Educational Technology 12 (2):200-216.

Acker, Frederik Van, Hans van Buuren, Karel Kreijns, and Marjan Vermeulen. 2013. "Why Teachers Use Digital Learning Materials: The Role of Self-Efficacy, Subjective Norm and Attitude." Education and Information Technologies 18 (3). Springer US:495-514. https://doi.org/10.1007/s10639-011-9181-9. 
Adesina, Aderonke A., and Charles K. Ayo. 2010. "An Empirical Investigation of the Level of Users' Acceptance of E-Banking in Nigeria." Journal of Internet Banking and Commerce 15 (1):1-13. https://doi.org/10.1007/978-3-531-925349_12.

Ajzen, Icek, and Martin Fishbein. 1975. "Belief, Attitude, Intention and Behavior: An Introduction to Theory and Research." Reading, MA: Addison-Wesley.

- 2000. "Attitudes and the Attitude-Behavior Relation: Reasoned and Automatic Processes." European Review of Social Psychology 11 (1). Taylor \& Francis:1-33.

Al-swidi, Abdullah, Sheikh M.R Huque, M.H Hafeez, and M.N.M Shariff. 2014. "The Role of Subjective Norms in Theory of Planned Behavior in the Context of Organic Food Consumption." British Food Journal 116 (10):1561-80. https://doi.org/10.1108/BFJ-05-2013-0105.

Alavi, Sepideh, and Marzieh Abdollahipour. 2014. "The Effect of Technology Confidence And Computer Accessibility on EFL University Students' Attittudes Toward The Use of Call in University Courses." International Journal of Language Learning and Applied Linguistics World 7 (3):289-99.

Anderson, Rolph E., and Srini S. Srinivasan. 2003. "E-Satisfaction and E-Loyalty: A Contingency Framework." Psychology and Marketing 20 (2):123-38. https://doi.org/10.1002/mar.10063.

Arbaugh, J B. 2000. "Virtual Classroom Characteristics and Student Satisfaction with Internet-Based MBA Courses." Journal of Management Education 24 (1):32-54. https://doi.org/10.1177/105256290002400104.

Ayo, Charles k., Aderonke Atinuke Oni, Oyerinde J. Adewoye, and Ibukun O. Eweoya. 2016. "E-Banking Users' Behaviour: E-Service Quality, Attitude, and Customer Satisfaction.” International Journal of Bank Marketing 34 (3):347-67. https://doi.org/10.1108/IJBM-12-2014-0175.

Bandura, Albert. 1977. "Self-Efficacy: Toward a Unifying Theory of Behavioral Change." Psychological Review 84 (2):191-215.

1997. Self-Efficacy: The Exercise of Control. Macmillan.

2001. "Social Cognitive Theory: An Agentic Perspective." Annual Review of Psychology 52 (1):1-26.

Bashir, I., and C. Madhavaiah. 2014. 'Determinants of Young Consumers' Intention to Use Internet Banking Services in India." Vision: The Journal of Business Perspective 18 (3). SAGE PublicationsSage India: New Delhi, India:153-63. https://doi.org/10.1177/0972262914538369.

Bora, Ronak. 2017. “Global E-Learning Market Size Worth USD 240 Bn by 2023 : Global Market Insights, Inc. - satPRnews.” 2017.

Bratkovič, Tina, Boštjan Antončič, and Alex F Denoble. 2017. "Relationships Between Networking, Entrepreneurial Self-Efficacy and Firm Growth : The Case Of Slovenian Companies." Ekonomska Istrazivanja 25 (1):61-71. https://doi.org/10.1080/1331677X.2012.11517494. 
Calisir, F., C. A. Gumussoy, and A. Bayram. 2009. "Predicting the Behavioral Intention to Use Enterprise Resource Planning Systems." Management Research News https://doi.org/http://dx.doi.org/10.1108/01409170910965215.

CEN/CENELEC/ETSI. 2014. "What Is ICT Accessibility? - Mandate 376.” 2014.

Chang, Yuan jen, Chin hsing Chen, Wen zeng Huang, and Wei Shiun Huang. 2011. "Investigating Students' Perceived Satisfaction, Behavioral Intention, and Effectiveness of English Learning Using Augmented Reality." 2011 IEEE International Conference on Multimedia and Expo, 1-6. https://doi.org/10.1109/ICME.2011.6012177.

Engel, James F, Roger D Blackwell, and Paul W Miniard. 1995. "Consumer Behavior, 8th." New York: Dryder.

Foong, Soon-Yau, and Choo-Hong Khoo. 2015. "Attitude , Learning Environment and Current Knowledge Enhancement of Accounting Students in Malaysia." https://doi.org/10.1108/JAEE-07-2012-0030.

Fourney, D.W., and J.A Cartera. 2006. "Ergonomic Accessibility Standards." Development 9241:171.

Fullerton, Gordon, and Shirley Taylor. 2015. "Dissatisfaction and Violation: Two Distinct Consequences of the Wait Experience." Journal of Service Theory and Practice 25 (1):31-50. https://doi.org/10.1108/JSTP-10-2013-0237.

GlobeNewswire. 2017. “Global E-Learning Market to Reach \$325 Billion by 2025 Rapid Growth in Online Content \&amp; Digitization / Innovations in Wearable Technologies Are Flourishing the E-Learning Industry." 2017.

Gopi, M, and T. Ramayah. 2007. "Applicability of Theory of Planned Behavior in Predicting Intention to Trade Online Some Evidence from a Developing Country." International Journal of Emerging Markets 2 (4):348-60. https://doi.org/10.1108/17468800710824509.

Grandon, Elizabeth E, Khaled Alshare, and Obyung Kwun. 2005. "Factors Influencing Student Intention to Adopt Online Classes: A Cross-Cultural Study." Journal of Computing Sciences in Colleges 20 (4). Consortium for Computing Sciences in Colleges:46-56.

Kim, Eojina, Sunny Ham, Il Sun Yang, and Jeong Gil Choi. 2013. "The Roles of Attitude, Subjective Norm, and Perceived Behavioral Control in the Formation of Consumers' Behavioral Intentions to Read Menu Labels in the Restaurant Industry." International Journal of Hospitality Management 35 (February). Elsevier Ltd:203-13. https://doi.org/10.1016/j.ijhm.2013.06.008.

Kim, Young Hoon, and Dan J Kim. 2005. “A Study of Online Transaction SelfEfficacy, Consumer Trust, and Uncertainty Reduction in Electronic Commerce Reduction in Electronic Commerce Transaction." In Proceedings of the 38th Hawaii International Conference on System Sciences -, 1-11. https://doi.org/10.1109/HICSS.2005.52.

Kompas.com. 2016. "Menilik Perkembangan E-Learning Di Asia Tenggara Kompas.com.” 2016. 
Kuo, Ying Feng, and Shieh Neng Yen. 2009. "Towards an Understanding of the Behavioral Intention to Use 3G Mobile Value-Added Services." Computers in Human Behavior 25 (1). Elsevier Ltd:103-10. https://doi.org/10.1016/j.chb.2008.07.007.

Laskowski, Sharon J., Marguerite Autry, John Cugini, William Killam, and James Yen. 2004. "Improving the Usability and Accessibility of Voting Systems and Products." NIST Special Publication 500-256, 1-92.

Latan, Hengky, and Imam Ghozali. 2012. Partial Least Squares: Konsep, Teknik Dan Aplikasi SmartPLS 2.0 M3. Semarang: Badan Penerbit Universitas Diponegoro.

Liaw, Shu Sheng. 2008. “Investigating Students' Perceived Satisfaction, Behavioral Intention, and Effectiveness of E-Learning: A Case Study of the Blackboard System." Computers and Education 51 (2):864-73. https://doi.org/10.1016/j.compedu.2007.09.005.

Liaw, Shu Sheng, Hsiu Mei Huang, and Gwo Dong Chen. 2007. "Surveying Instructor and Learner Attitudes toward E-Learning." Computers and Education 49 (4):1066-80. https://doi.org/10.1016/j.compedu.2006.01.001.

Loureiro, S.M.C, Hans R. Kaufmann, and Samuel Rabino. 2014. "Intentions to Use and Recommend to Others." Online Information Review 38 (2):186-208. https://doi.org/10.1108/OIR-01-2012-0100.

Lucas, Henry C., and V.K. Spitler. 1999. "Technology Use and Performance: A Field Study of Broker Workstations." Decision Sciences 30 (2):291-312. https://doi.org/10.1111/j.1540-5915.1999.tb01611.x.

Mayer, Roger C, James H Davis, and David F Schoorman. 1995. "An Integrative Model of Organizational Trust." Academy of Management Review 20 (3):70934.

Mayya, S. 2007. "Integrating New Technology To Commerce Curriculum : How To Overcome Teachers ' Resistance ?" The Turkish Online Journal of Educational Technology - TOJET 6 (1):8-15.

Mckinney, Vicki, Kanghyun Yoon, and Fatemeh Mariam. 2002. "The Measurement of Web-Customer Satisfaction : An Expectation and Disconfirmation Approach." Information Systems $\quad$ Research $13 \quad$ (3):296-315. https://doi.org/10.1287/isre.13.3.296.76.

Meyer, J.P, and N.J Allen. 1997. Commitment in the Workplace: Theory, Research, and Application. Newbury Park, CA: SAGE Publications.

Miller, Joan, and B.a. Doyle. 1987. "Measuring the Effectiveness of Computer -Based Information Systems in the Financial Services Sector." MIS Quarterly 11 (1):107-24.

Naile, Siso. 2017. "E-Learning Solutions Provide Easy Learning | Roodepoort Northsider." 2017.

Ndubisi, Nelson Oly. 2006. "Factors of Online Learning Adoption: A Comparative Juxtaposition of the Theory of Planned Behaviour and the Technology Acceptance Model.” International Journal on ELearning 5 (4). Association for the Advancement of Computing in Education:571. 
Oliver, Richard L. 1980. "A Cognitive Model of the Antecedents and Conseqences of Satisfaction Decisions." Journal of Marketing Research (JMR) 17 (4):460-69. https://doi.org/10.1017/CBO9781107415324.004.

Ozkan, Sevgi, and Refika Koseler. 2009. "Multi-Dimensional Students' Evaluation of E-Learning Systems in the Higher Education Context: An Empirical Investigation." Computers \& Education 53:1285-96. https://doi.org/10.1016/j.compedu.2009.06.011.

Ozkan, Sevgi, Refika Koseler, and Nazife Baykal. 2009. "Evaluating Learning Management Systems Adoption of Hexagonal E-Learning Assessment." Transforming Government: People, Process and Policy 3 (2):111-30. https://doi.org/10.1108/17506160910960522.

Park, Sung Youl. 2009. "An Analysis of the Technology Acceptance Model in Understanding University Students' Behavioral Intention to Use E-Learning.” Journal of Educational Technology \& Society 12 (3):150-62.

Pérez, Rafael Curras, Carla Ruiz Mafe, and Silvia Sanz Blas. 2013. "Social Network Loyalty: Evaluating the Role of Attitude, Perceived Risk and Satisfaction." Online Information Review $37 \quad$ (1):61-82. https://doi.org/10.1108/14684521311311630.

Peslak, Alan R, Girish H Subramanian, and George E Clayton. 2007. "The Phases of ERP Software Implementation and Maintenance: A Model for Predicting Preferred ERP Use.” Journal of Computer Information Systems 48 (2):25-33. https://doi.org/10.1080/08874417.2008.11646006.

Ranaweera, Chatura, Harvir Bansal, and Gordon McDougall. 2008. "Web Site Satisfaction and Purchase Intentions: Impact of Personality Characteristics during Initial Web Site Visit." Managing Service Quality: An International Journal 18 (4):329-48. https://doi.org/10.1108/09604520810885590.

Rice, R.E, and D.E Shook. 1988. "Access To, Usage Of, and Outcomes from an Electronic Messaging System." ACM Tranactions on Office Infrormation Systems 6 (3):255-76.

Ryu, Kisang, Hye- Rin Lee, and Woo Gon Kim. 2012. "The Influence of the Quality of the Physical Environment, Food, and Service on Restaurant Image, Customer Perceived Value, Customer Satisfaction, and Behavioral Intentions." International Journal of Contemporary Hospitality Management 24 (2):200-223. https://doi.org/10.1108/09596111211206141.

Saadé, Raafat George. 2003. "Web-Based Educational Information System for Enhanced Learning, EISEL: Student Assessment." Journal of Information Technology Education 2 (1):267-277.

Sachs, David, and Nancy Hale. 2003. "Pace University's Focus on Student Satisfaction With Student Services in Online Education.” JALN 7 (2):36-42.

Sanakulov, Nodir, and Heikki Karjaluoto. 2015. "Consumer Adoption of Mobile Technologies: A Literature Review." International Journal of Mobile Communications 13 (3):244. https://doi.org/10.1504/IJMC.2015.069120.

Sawang, Sukanlaya, Cameron Newton, and Kieren Jamieson. 2013. "Increasing 
Learners' Satisfaction/intention to Adopt More E-Learning." Education + Training 55 (1):83-105. https://doi.org/10.1108/00400911311295031.

Shittu, Ahmed Tajudeen, Kamal Madarsha Basha, N.S.N AbdulRahaman, and T.B.T Ahmad. 2011. "Investigating Students' Attitude and Intention to Use Social Software in Higher Institution of Learning in Malaysia." Multicultural Education $\begin{array}{llll}\text { \& Technology } & \text { Journal } & 5 & \text { (3):194-208. }\end{array}$ https://doi.org/10.1108/17504971111166929.

Sun, Pei Chen, Ray J. Tsai, Glenn Finger, Yueh Yang Chen, and Dowming Yeh. 2007. "What Drives a Successful E-Learning? An Empirical Investigation of the Critical Factors Influencing Learner Satisfaction." Computers and Education 50 (4):1183-1202. https://doi.org/10.1016/j.compedu.2006.11.007.

Teng, Chih-Ching, and Yu-Mei Wang. 2015. "Decisional Factors Driving Organic Food Consumption Generation of Consumer Purchase Intentions." British Food Journal Vol. 117 (No. 3):1066-81. https://doi.org/10.1108/BFJ-12-2013-0361.

Venkatesh, V, and Fd Davis. 2000. "A Theoretical Extension of the Technology Acceptance Model: Four Longitudinal Field Studies." Management Science 46 (2):186-204. https://doi.org/WOS:000086130700002.

Verplanken, Bas, and Rob W Holland. 2002. "Motivated Decision Making: Effects of Activation and Self-Centrality of Values on Choices and Behavior." Journal of Personality and Social Psychology 82 (3):434-47. https://doi.org/10.1037//00223514.82.3.434.

Vesalainen, Jukka, and Timo Pihkala. 1999. "Entrepreneurial Identity, Intentions and Effect of The Push Factor." Academy of Entrepreneurship Journal 5 (2):1-24.

Villiers, Roxy de. 2017. "Nine Facts You Should Know about E-Learning | Randfontein Herald." 2017.

Voon, Jan P., Kwang Sing Ngui, and Anand Agrawal. 2011. "Determinants of Willingness to Purchase Organic Food: An Exploratory Study Using Structural Equation Modeling." International Food and Agribusiness Management REview 14 (2):103-20.

Whittaker, Graham, Lesley Ledden, and Stavros P. Kalafatis. 2007. "A ReExamination of the Relationship between Value, Satisfaction and Intention in Business Services." Journal of Services Marketing 21 (5):345-57. https://doi.org/10.1108/08876040710773651.

Yau, Hon Keung, and Tsz Chung Ho. 2015. "The Influence of Subjective Norm on Behavioral Intention In Using E-Learning: An Empirical Study in Hong Kong Higher Education." In Proceedings of the International MultiConference of Engineers and Computer Scientists, II:18-20. Hong Kong. 


\section{LAMPIRAN}

Tabel 2

Pengukuran Validitas and Reliabilitas

\begin{tabular}{|c|c|c|}
\hline & Kontruks \& item & $\begin{array}{l}\text { Outer } \\
\text { Loading }\end{array}$ \\
\hline e-learn & ig Self -efficacy (SE) $(C R=0,940, A V E=0,760)$ & \\
\hline SE1 & Saya merasa percaya diri ketika mencari informasi pada sistem $e$-learning & 0,818 \\
\hline SE2 & $\begin{array}{l}\text { Saya memiliki keterampilan yang dibutuhkan untuk menggunakan sistem } \\
\text { e-learning ini }\end{array}$ & 0,728 \\
\hline SE3 & Saya merasa percaya diri ketika menggunakan sistem $e$-learning ini & 0,937 \\
\hline SE4 & Saya merasa percaya diri ketika mengoperasikan fungsi $e$-learning ini & 0,922 \\
\hline SE5 & Saya merasa percaya diri ketika menggunakan konten dari e-learning ini & 0,934 \\
\hline Subjec & ve Norm $(\mathrm{SN})(C R=0,895, A V E=0,740)$ & \\
\hline SN1 & e-learning ini (Moodle) penting bagi saya sebagai mahasiswa. & 0,801 \\
\hline SN2 & $\begin{array}{l}\text { Saya suka menggunakan e-learning ini karena kegunaannya sesuai dengan } \\
\text { nilai-nilai saya. }\end{array}$ & 0,869 \\
\hline SN3 & $\begin{array}{l}\text { Saya suka menggunakan e-learning ini karena kegunaannya sesuai dengan } \\
\text { nilai-nilai sosial. }\end{array}$ & 0,907 \\
\hline Akses & istem (SA) $(C R=0,982, A V E=0,965)$ & \\
\hline SA1 & $\begin{array}{l}\text { Saya tidak menghadapi kesulitan dalam mengakses sistem e-learning ini } \\
\text { (moodle) di Universitas }\end{array}$ & 0,979 \\
\hline SA2 & $\begin{array}{l}\text { Saya tidak menghadapi kesulitan dalam menggunakan sistem e-learning ini } \\
\text { (moodle) di Universitas. }\end{array}$ & 0,986 \\
\hline Sikap & $R=0,916, A V E=0,785)$ & \\
\hline SK1 & Belajar melalui e-learning adalah ide yang bagus. & 0,920 \\
\hline SK2 & Belajar melalui e-learning adalah ide yang bijaksana. & 0,883 \\
\hline SK3 & Saya merasa positif terhadap e-learning & 0,853 \\
\hline Niat $\mathbf{p}$ & ilaku $(C R=0,904, A V E=0,825)$ & \\
\hline NP1 & $\begin{array}{l}\text { Saya berniat untuk mengecek pengumuman dari sistem e-learning (secara } \\
\text { regular. }\end{array}$ & 0,900 \\
\hline NP2 & Saya berniat untuk menjadi pengguna berat dari sistem $e$-learning ini. & 0,916 \\
\hline Kepua & an $(C R=0,967, A V E=0,881)$ & \\
\hline KEP1 & Saya puas menggunakan e-learning sebagai alat membantu pembelajaran. & 0,929 \\
\hline KEP2 & Saya puas menggunakan fungsi $e$-learning & 0,942 \\
\hline KEP3 & Saya puas dengan isi dari e-learning. & 0,958 \\
\hline KEP4 & Saya puas dengan instruksi multimedia dari e-learning. & 0,925 \\
\hline
\end{tabular}

Sumber: Hasil pengolahan data PLS, 2017 
